\title{
VOĐENJE KAO NEZAOBILAZNA FUNKCIJA SUDIONIKA ODGOJNO-OBRAZOVNOG PROCESA U SUVREMENOM VRTIĆKOM KONTEKSTU
}

Apstrakt: Kvalitetno obavljanje odgojno-obrazovne djelatnosti u kontekstu suvremenih ustanova ranog i predškolskog odgoja i obrazovanja zahtijeva profesionalno pedagoška, didaktička i metodička znanja stečena kroz inicijalno obrazovanje, ali i dodavanje i primjenu brojnih drugih kompetencija. U radu je analiziran kontekst ustanove za rani i predškolski odgoj i obrazovanje u svjetlu suvremenih paradigmi u odgoju i obrazovanju iz kojih nedvojbeno proizlazi potreba stjecanja novih kompetencija s naglaskom na voditeljske kompetencije koje postaju bitna pedagoška svojstva svih nositelja odgojno-obrazovnog procesa (odgojitelja, stručnih suradnika i ravnatelja). Akceptiranjem vođenja kao procesa kojim se u određenim situacijama nastoji utjecati na pojedinca ili grupu kako bi se postigli određeni ciljevi otvara se potreba višedimenzionalnog pogleda na taj fenomen.

Ključne riječi: menadžment, menadžment u obrazovanju, obrazovanje, ustanove ranog i predškolskog obrazovanja, vođenje (liderstvo).

\section{UVOD}

Menadžment je institucija koja se pojavila u povijesti ljudskog rada iznenada i za manje od 150 godina preobratila društvenu i ekonomsku strukturu razvijenih zemalja u cijelome svijetu, što je dovelo do stvaranja globalne ekonomije, ali i vlastite preobrazbe (Drucker, 2005). Prisutnost mnadžmenta bilježi se u svim vrstama ljudskih organizacija i u tom smislu nije zaobiđen niti obrazovni sustav. Seme Stojnović i Hitrec (2014) navode

\footnotetext{
*Jadranka Stojković, jadranka.stojkovic1@gmail.com
} 
kako se pojmovi vođenje, rukovođenje, upravljanje i menadžment najprije susreću u školskom sustavu i tek potom u području ranog i predškolskog odgoja i obrazovanja. U ovom radu fenomen vođenja smješten je u kontekst ustanova ranog i predškolskog odgoja i obrazovanja i analizirati će se u svjetlu suvremenih pedagoških paradigmi.

Ustanove za rani i predškolski odgoj i obrazovanje su mjesta zajedničkog učenja i poučavanja svih sudionika odgojno-obrazovnog procesa: djece, odgojitelja, stručnih suradnika i ravnatelja. Imperativ suvremene koncepcije odgoja i obrazovanja koja je utemeljena na humanističkom i razvojno-individualističkom pristupu je složena interakcija i komunikacija te ravnomjerno sudjelovanje svih sudionika odgojnoobrazovnog procesa, što pretpostavlja i distribuciju moći i odgovornosti na sve sudionike odgojno-obrazovnog procesa. Na kvalitetu ustanove za rani i predškolski odgoj i obrazovanje utječu okruženje, ozračje, uvjerenja, vrijednosti, odnosi, komunikacija i vođenje (liderstvo).

Posebnost područja ranog i predškolskog odgoja i obrazovanja u Republici Hrvatskoj i to posebnost pozitivnog predznaka evidentna je i vidljiva kroz povijesni razvoj uvođenja novih pristupa i implementaciju suvremenih paradigmi bez prevelikih očekivanja $\mathrm{u}$ pogledu promjena $\mathrm{i}$ direktive obrazovnih politika kako u teorijskim diskursima tako i u akcijskim istraživanjima same prakse. Proaktivno djelovanje teorije i prakse vidljivo je i kroz sledeće programske dokumente:

„Program odgojno-obrazovnog rada u dječjem vrtiću” (1971) ima obilježje tradicionalnog, bihevioralnog kurikuluma. Usmjeren je na učenje i poučavanje, a manje na samo dijete. Ciljevi, zadaci i sadržaji rada utvrđeni su po područjima rada. 
„Osnove programa za odgojno-obrazovni rad s djecom predškolskog uzrasta” (1983) je dokument koji, unatoč utvrđenim sadržajima rada i minoriziranom važnošću okruženja, ipak ukazuje na potrebu veće fleksibilnosti i cjelovitijeg pristupa djetetovu razvoju i odgoju.

„Programsko usmjerenje odgoja i obrazovanja” (1991) predstavlja humanističko-razvojnu koncepciju odgoja i obrazovanja koja polazi od potreba i prava djece. Učenje se temelji na teoriji konstruktivizma i sukonstruktivizma, te se naglašava važnost osmišljenog i poticajnog okruženja koje je primjereno individualnim i razvojnim potrebama djeteta.

„Nacionalni okvirni kurikulum za predškolski odgoj i obrazovanje te opće obvezno i srednjoškolsko obrazovanje” (2011) je dokument u kojem se dijete predstavlja kao jedinstveno proaktivno biće bogato potencijalima i kao sukreator svojeg razvoja.

„Nacionalni kurikulum za rani i predškolski odgoj i obrazovanje” (2014) razvija ideje iz Programskog usmjerenja odgoja i obrazovanja predškolske djece. Temelji se na suvremenom shvaćanju djeteta kao cjelovitog bića i subjekta sa specifičnom kulturom, pravima i potrebama. U središtu su mu vrijednosti, načela i ciljevi, a ne sadržaji, usmjeren je na odnose i na ostvarenje obvezuje sve sudionike koji obavljaju odgojnoobrazovnu djelatnost i šire. Zasniva se na načelima slobode, raznolikosti, otvorenosti i demokracije te promiče ideje slobode i pluralizma u primjeni pedagoških ideja i oblicima provođenja programa.

\section{MENADŽMENT I VOĐENJE U ODGOJNO-OBRAZOVNOM SUSTAVU}

Prisutnost menadžmenta bilježi se u svim vrstama organizacija pa se je tako iz područja ekonomije i poslovnog svijeta pojavio i u sustavu odnosno 
institucijama odgoja i obrazovanja i tamo se susreće pod različitim nazivima kao što su organizacijski menadžment, menadžment $\mathrm{u}$ obrazovanju, obrazovni menadžment, pedagoški menadžment, menadžment razina i slično (Jurić, 2004; Resman, 2001; Staničić, 2006). Jurić (2004) izdvaja četiri razine menadžmeta u odgojno-obrazovnom sustavu $\mathrm{s}$ obzirom na formalne voditelje: 1. razvojni djelatnici, odgojitelji, učitelji i nastavnici; 2. ravnatelji; 3. savjetnici i 4. ministar. Nadalje navodi kako se i sustavima upravlja pa u tom kontekstu razlikuje: menadžment odgojno-obrazovnog sustava, menadžment predškolskog sustava, menadžment predškolskih institucija, menadžment školskog sustava, menadžment školskih institucija.

Menadžment se kao pojava, pojam ili institucija vremenom sve više zamjenjuje s vođenjem. Za razliku od područja ekonomije transfer od fenomena menadžmenta ka fenomenu vođenja u području odgoja i obrazovanja vidljiviji je i odvija se mnogo brže. Može se zaključivati da je fenomen vođenja $u$ odnosu na fenomen menadžmenta $u$ sustavu odgoja $i$ obrazovanja zauzeo dominaciju.

Vođenje u odgojno-obrazovnom sustavu jeste proces povezivanja i usklađivanja stručnih potencijala radi realizacije zacrtanih ciljeva, a za realizaciju kojih odgovornost leži na svim sudionicima odgojno-obrazovnog procesa (Staničić, 2006). Resman (2001) smatra kako viziju škole kao poželjnu sliku njezine budućnosti u kojoj će se događati promjene postojećeg stanja i uvoditi inovacije treba graditi na uključenosti i suradnji svih koji su uključeni u njezin rad. Muldoon (2015) navodi da se okruženje povjerenja i poštovanja $u$ kojem se pojedinci cijene zbog svojih ideja i svojeg sudjelovanja stvara zahvaljujući modelu suradničkog vođenja te ističe kako sudjelovanje potiče kretanje prema ciljevima. Čak i kad postoje različite 
ideje, odgovornost za stvaranje partnerskih odnosa pripada vođenju koje treba razumjeti kao kompleksne veze kako unutar vlastitog fakulteta tako i u vanjskom okruženju.

U traženju odgovora zašto je jedna ustanova uspješnija od druge uočeno je da postoji korelacija između utjecaja vođe i uspješnosti neke organizacije, što se propitivalo mnogim istraživanjima (Staničić, 2006). Rezultati koje je nakon provedenog istraživanja među zaposlenicima svih razina u državnim i privrednim organizacijama dobio Konja (2014) nedvosmisleno su utvrdili kako komunikacija između lidera i suradnika u značajnoj mjeri utječe na organizacijsku posvećenost zaposlenih. Peko, Mlinarević i Gajger (2009) istraživale su kako učitelji i pedagozi percipiraju kvalitetu vođenja škola te kakva je povezanost između vođenja škole i školskog ozračja, organizacijske učinkovitosti i zadovoljstva poslom. Prema rezultatima empirijskog istraživanja koje su provele na 265 ispitanika od čega je 85 stručnih suradnika i 180 učitelja osnovnih škola sve su varijable ostvarile značajnu statističku povezanost, vođenje, školsko ozračje, organizacijska učinkovitost i zadovoljstvo poslom predstavljaju važne faktore učinkovitog vođenja u hrvatskim osnovnim školama.

\section{KONTEKSTUALNO ODREĐENJE USTANOVA RANOG I PREDŠKOLSKOG ODGOJA I OBRAZOVANJA}

Današnje, suvremene spoznaje o djetetu i djetinjstvu imperativ su rada ustanova za rani i predškolski odgoj i obrazovanje. Dijete se percipira kao kreativno i aktivno i za izražavanje vlastitih i stjecanje novih iskustava neophodna mu je stimulativna, afektivna, višedimenzionalna sredina. Poticajno okruženje u kojem dijete boravi ima poseban značaj jer dijete uči promatrajući, čineći i sudjelujući. Socio-pedagoško okruženje, kako navode 
Došen-Dobud (1982), Mlinarević (2004), Petrović-Sočo (2007), važan je čimbenik cjelokupnog razvoja svakog djeteta i temelj je njegovoga daljnjeg razvoja. Kvalitetno okruženje podrazumijeva takve uvjete koji će omogućiti nesmetanu i kvalitetnu komunikaciju na svim relacijama: relaciji dijetedijete/djeca, na relaciji dijete/djeca-odgojitelj, te kvalitetnu komunikaciju svih ostalih dionika odgojno-obrazovnog procesa (Jurčević-Lozančić, 2011).

Važnost okruženja u kojem dijete boravi, okruženja koje potiče i omogućuje humane, socijalne i emocionalne odnose među svim sudionicima odgojno-obrazovnog procesa proučavale su i istraživale mnoge autorice (Miljak, 2001; Petrović-Sočo, 2007; Slunjski, 2006; Šagud, 2006; Vujičić, 2008). Nova slika djeteta i djetinjstva koju donose suvremene znanstvene spoznaje polazište je za oblikovanje svih segmenata odgojno-obrazovnog procesa u suvremenoj ustanovi te izravno utječe na oblikovanje kurikuluma. „Ostvarivanje kvalitetnog kurikuluma vrtića podrazumijeva stvaranje odgovarajućih organizacijskih uvjeta koji se temelje na suvremenom shvaćanju djeteta, tj. shvaćanju djeteta kao cjelovitog bića“" (Nacionalni kurikulum, 2014:33). Slijedom navedenoga, kontekstu vrtića odgovara sintagma „živi organizam“ ili „živući sustav“ i konstatacija da je njegovo „zdravlje“ uvjetovano zdravim i skladnim funkcioniranjem svih njegovih podsustava (Rinaldi, 2006; Strozzi, 2002 prema Slunjski, 2015).

Suvremene ustanove za rani i predškolski odgoj i obrazovanje mjesto su zajedničkog učenja i poučavanja, kvalitetnog življenja i ravnopravnog sudjelovanja, no, kako navodi Fullan (2003), da bismo učinili i najmanju promjenu u okruženju moramo mijenjati prije svega svoje ponašanje. Kvaliteta zajedničkog rada odgojitelja i drugih stručnih djelatnika koja podrazumijeva i zajedničku odgovornost, promišljanje i analiziranje odgojne prakse kroz timski 
pristup te način razmišljanja o vlastitoj odgojno-obrazovnoj ulozi neke su od temeljnih odrednica definirane u Priručniku za samovrednovanje ustanova ranog i predškolskog odgoja i obrazovanja (2012).

Pokretači i provoditelji odgojno-obrazovnog procesa su ljudi, odgojitelji, nastavnici, djeca, učenici i svaki od njih ima svoju važnu i specifičnu ulogu. Odgojitelji, učitelji, nastavnici samostalno vode i organiziraju odgojno-obrazovni proces na osnovu znanja o pedagogiji, didaktici, metodici, no oni su duboko svjesni ili bi trebali biti da ne odgajaju samo metode i postupci nego i njihova ličnost, te da odgoj i obrazovanje bez aktivne participacije djece, učenika nije moguć (Bognar i Matijević, 2005; Jurčić, 2012). Svojim zalaganjem i profesionalno pedagoškim kompetencijama, kreativnošću i stvaralačkom otvorenošću odgojitelji, učitelji, stručni suradnici i ravnatelj stvaraju pretpostavke razvoja i uspjeha, te vode ustanovu ka ostvarenju vizije čije se ishodište nalazi u kulturi i ozračju. U kontekstu povezanosti vođenja i kulture u ustanovi Vujičić (2008) navodi da osim formalnog vođenja, važnu ulogu unutar ustanove, u procesu prenošenja (i stvaranja) kulture imaju i drugi djelatnici (pojedinačno i grupno).

Odgojitelji su neposredni provoditelji odgojno-obrazovnog procesa u skupini, oblikuju ga $\mathrm{i}$ vode, te na njega imaju izravan utjecaj. U profesionalnom radu suvremeni odgojitelj je inicijator, uzor, kreator odgojnih promjena i međuljudskih odnosa što spada u domenu liderskih kompetencija. Profesionalno-pedagoške kompetencije odgojitelja proizlaze iz njihovih osobnih sposobnosti koje čine skup vrijednosti čije se ishodište nalazi u genetici, ali su i rezultat iskustva te odgoja i obrazovanja, stoga karakteristike kao što su svjetonazor, temperament i slično spadaju u osobne kompetencije. Osobne kompetencije reflektiraju se na neki način i na implicitnu pedagogiju 
koju nalazimo kod odgojitelja (ali i ostalih praktičara). Slunjski (2009) to potvrđuje provedenim akcijsko-etnografskim istraživanjem koje se provodilo u razdoblju od četiri godine u četiri različite ustanove ranoga i predškolskoga odgoja i obrazovanja. Među ostalim, istraživanjem se htjelo ustanoviti u kakvom su međuodnosu suvremene paradigme i eksplicitna znanja u odnosu na konkretnu odgojno-obrazovnu praksu (implicitnim znanjima). Kvalitativnim i interpretativnim istraživačkim pristupom došlo se do rezultata koji dokazuju da znanstvena paradigma sama po sebi nema veliki utjecaj na odgojnoobrazovnu praksu, nego njome više upravljaju osobne paradigme, odnosno osobne teorije pojedinih praktičara.

„Kompetentna praksa zahtijeva kompetentnog odgojitelja“ (Slunjski, 2015:31), a unapređenje odgojno-obrazovne prakse u ustanovi zahtijeva kontinuirano učenje i stručno usavršavanje, dakle profesionalni razvoj odgojitelja i svih ostalih stručnih djelatnika. Rezultati istraživanja koje su provele Stojković, Katovčić (2016) u Dječjem vrtiću Radost u Jastrebarskom na populaciji od 47 odgojitelja, a s ciljem ispitivanja gledišta odgajatelja o vlastitom stručnom usavršavanju, pokazali su da odgojitelji neovisno o dobi procjenjuju da im formalno obrazovanje nije dovoljno za kvalitetan odgojnoobrazovni rad, te da im je potrebno kontinuirano stručno usavršavanje. Prilike i pristupi stručnom usavršavanju u ustanovi procjenjuju kvalitetnima te su $\mathrm{u}$ korelaciji s percepcijom vlastitih kompetencija $(r=0,459 ; \mathrm{p}=0,001)$.

Autoritet i utjecaj stručnih suradnika temelji se na njihovoj stručnosti i profesionalnosti, a ne proizlazi iz formalne uloge. Suvremena pedagoška djelatnost pred sve profile stručnih suradnika u ustanovama za rani i predškolski odgoj i obrazovanje postavlja svakodnevne izazove. Općenito gledano rad stručnih suradnika u teoriji i praksi je upravljanje ljudskim 
resursima, za što su potrebne odgovarajuće stručne kompetencije kako bi se profesionalne zadaće uspješno realizirale. Zadaće stručnih suradnika su, općenito gledajući, savjetodavni rad, motivacija suradnika te realizacija kurikularnih ciljeva. Komunikacija je u osnovi rada stručnih suradnika dio svakodnevne prakse stoga se komunikacijske i voditeljske vještine smatraju ključnim kompetencijama svakog stručnog suradnika ukoliko želi imati i razvijati kvalitetne i na profesionalnim osnovama zasnovane međuljudske odnose.

Iako svaki sudionik odgojno-obrazovnog procesa djeluje sa svog stručnog aspekta, suradnja i zajednički, timski rad doprinose unapređenju rada kao i lakšem suočavanju s potencijalnim izazovima. S tim u vezi zanimljivi su i indikativni rezultati istraživanja koje je proveo Sindik (2012). $\mathrm{Na}$ uzorku od 401 ispitanika koje su činili odgojitelji i stručni suradnici (pedagozi, psiholozi, logopedi, edukacijski rehabilitatori i zdravstveni voditelji) dječjih vrtića grada Zagreba $\mathrm{s}$ ciljem utvrđivanja razlike $\mathrm{u}$ doživljaju timske suradnje između navedenih stručnjaka. Dobivenim rezultatima utvrđena je statistički značajna razlika u doživljaju aspekata timske učinkovitosti s obzirom na zanimanje odnosno posao koji obavljaju u ustanovama za rani i predškolski odgoj i obrazovanje. Odgojitelji negativnije percipiraju aspekte timskog rada kao što su stimulativnost, učinkovitost, osobni utjecaj, kriteriji vrednovanja i emocionalno vrednovanje što znači da negativnije od stručnih suradnika percipiraju i timsku učinkovitost.

Staničić (2005) navodi kako su pedagogu za optimalno ostvarenje njegove uloge potrebne odgovarajuće kompetencije koje obuhvaćaju znanja, karakteristike i stručne kvalifikacije. S tim u vezi proveo je empirijsko istraživanje poželjnih kompetencija, a rezultati provedenog istraživanja 
portretirali su školskog pedagoga kao stručnjaka koji dobro poznaje didaktički aspekt odgojno-obrazovnog proces, ima sposobnost motiviranja suradnika na kvalitetni doprinos u radu, uspješno uvodi inovacije u pedagoški rad škole, te ima sposobnosti stvarati i razvijati kvalitetne međuljudske odnose, a pritom ga odlikuju iskrenost, otvorenost te spremnost davanja stručnih savjeta.

Ravnatelj je formalni voditelj ustanove, i, kako navodi Staničić (2006), njegova je voditeljska uloga determinirana obvezama sankcioniranim u pravno-administrativnoj regulativi. Uloga ravnatelja, kako navode Andevski, Budić i Gajić (2015), jeste uključivanje nastavnika/odgojitelja u sve segmente funkcioniranja ustanove kao zajednice u kojoj svaki pojedinac participira u kreiranju zajedničke vizije. U ustanovama ranog i predškolskog odgoja i obrazovanja ravnatelji imaju obvezu „stvarati“ voditelje od svih djelatnika, odgajatelja i stručnih suradnika. Valja imati na umu da se „suvremeni ravnatelj susreće s ogromnim dijapazonom razlika kad su u pitanju“ zaposlenici, oni se razlikuju po radnom iskustvu i obrazovanju, različita im je motivacija za rad osobito kad je u pitanje uvođenje inovativnosti, različito se odnose spram osobnog i profesionalnog razvoja stoga mu je u odnosu na njih uloga sve zahtjevnija (Staničić, 2006: 149).

\section{ULOGA KOJE MOŽDA NISMO, A TREBALI BISMO BITI SVJESNI}

Vođenje je stalno prisutno među ljudima bilo da se radi o privatnim ili poslovnim situacijama (Seme Stojnović i Hitrec, 20014). U procesima vođenja neminovno su prisutni i voditelji koji stalno donose odluke. „U svakom izvršiteljskom poslu može biti mnogo odluka (...) u situaciji kad je odluka 
nužna, a ne donosi se iz nekog razloga (...), odluka je također donijeta - odluka o odlaganju odluke“ (Tudor, Rijavec i Zarevski, 2009: 284).

Maxwell (2003) navodi kako je u grupi lako uočiti osobu koja vodi, mišljenje te osobe prihvaća većina ljudi, ta osoba je u fokusu grupe kad se raspravlja, dogovara, odlučuje. Sposobnost promišljanja i planiranja unaprijed te sposobnost donošenja odluka prema prioritetima čine ključnu razliku između voditelja i sljedbenika, zaključuje isti autor.

„Ako postoji istina o ljudima koju nitko ne može negirati, onda je to istina da je uspjeh u bilo kojem području upravo proporcionalan načinu na koji se ljudi u nekom odnosu slažu jedni s drugima. Ovu istinu možemo jasno sagledati (....) i na radnim mjestima“ (Glasser, 2004:29). Za ostvarenje ciljeva, realizaciju zadataka ili odgovora na izazove važna je suradnja zaposlenika različitih obrazovnih razina $i$ različitih specijaliziranih usmjerenja što pretpostavlja rad u timovima, navodi Klippert (2000). „Bez obzira na to gdje su timovi, na vrhu ili dnu organizacijske piramide, sačinjavali ih direktori, službenici ili drugi djelatnici, njihov se prvi čovjek uvijek naziva voditeljem tima“" (Tudor i Srića, 2014: 156).

U kontekstu svake organizacije nalaze se osobe $\mathrm{s}$ određenim odgovornostima i ulogama pa su neki od njih voditelji, neki sljedbenici. „Bila bi velika pogreška rukovodećim osobljem smatrati samo one koji su vidljivi ili se o njima govori u medijima. (...) i majstor u tvornici ispunjava neke rukovodeće zadaće, pa je stoga i on menadžer (voditelj). On možda u hijerarhijskoj ljestvici nije poput svojega nadređenog, no dovoljno je važan da ispunjava neke rukovodeće zadatke te ga se mora ozbiljno shvaćati“" (Malik, 2009: 48). Unatoč postojanju određene hijerarhije u organizaciji, ustanovi i slično, ona gubi (negativan) smisao ukoliko su voditelji usmjereni na ostvarenje ciljeva, a ne 
razmišljaju o svojem mjestu u hijerarhiji (Malik, 2009). „Ponašanje lidera je pre svega u funkciji karakteristika saradnika i karakteristika okruženja (...) koje podrazumeva potpuno uključivanje svih učesnika u poslovnim procesima“ (Grubić Nešić, 2008: 27).

Drucker (2006) zajedničke ciljeve svih zaposlenih uspoređuje s partiturom koju imaju i dirigent opere (voditelj) i orkestar (ostali zaposleni). Nema više ili manje važnih, nego je važno samo tko je odgovoran za što. Autor dalje navodi da ,nije riječ o suzdržavanju od izdavanja naređenja, već treba znati kad treba nešto narediti, a kad se prema nekome odnositi kao partner“ (Drucker, 2006: 69). Kako navode Ristić i sur. (2008), svaki je radnik u određenom smislu menadžer, jer bez obzira na vrstu posla koji obavlja ima obvezu upravljanja svojim radnim mjestom i svojim osobnim razvojem (obrazovanjem). Isti autori dalje navode kako smo svi u određenim situacijama voditelji bez obzira na poziciju, i kako se moramo ponašati u skladu s tom ulogom, napose trebamo preuzeti odgovornost za rezultate. Stoga su svim radnicima potrebne voditeljske kompetencije i umijeće vođenja, dakle svi su lideri, iako nisu svi isti. „Svaki je čovjek vođa jer svi na nekoga utječemo. Nećemo svi postati vrhunski vođe, ali svatko od nas može postati još bolji vođa“ (Maxwell, 2003: 29). Identificiranje i pružanje profesionalne podrške potencijalnim voditeljima obveza je neposrednih voditelja, navode Kovač, Mayer i Jesenko (2004), ali preduvjet toga je zrelost voditelja, autorova promišljanja imputiraju odgovornost plus za formalne voditelje.

Tudor i sur. (2009: 301) znakovito izjavljuju: „Omogućite ljudima da sudjeluju, kreiraju, budu autonomni! To je jedan od najjačih načina izazivanja njihove motivacije“, i zasigurno pritom nemaju na umu organizacije $s$ tradicionalnom organizacijskom strukturom, već organizacije koje omogućuju 
efektivni transfer znanja i informacija među zaposlenicima, postojanje zajedničke vizije jasne na svim razinama, organizacije koje omogućuju inovativnost, eksperimentiranje i fleksibilnost, te razvoj individualne odgovornosti za performanse i razvoj karijere. Kako ističu Dimovski, Penger i Peterlin (2009), vođe imaju obvezu osigurati takvo okruženje u kojem odgovornost za ostvarenje vizije osjećaju svi zaposleni što u konačnosti zahtijeva autentičnu predanost vođe i svih zaposlenih vrijednostima učenja.

Očekivano različita ponašanja ljudi u organizaciji između ostalog mogu biti posljedica različitih pogleda na ista događanja i toga mora biti svjestan vođa zbog značaja njegove uloge u stvaranju povoljne organizacijske klime, navodi Srića (2004), i dodaje da je zbog različitosti kulturnih okruženja načine vođenja potrebno prilagoditi kulturnom okruženju u kojem se vođenje događa.

\section{PERCEPCIJA VOĐENJA U USTANOVAMA RANOG I PREDŠKOLSKOG ODGOJA I OBRAZOVANJA}

Proces vođenja u ustanovama ranog i predškolskog odgoja i obrazovanja kako navodi Goddard (2003, prema Slunjski, 2018) ne može se izdvojiti iz konteksta u kojem se događa, a kako nije statična kategorija ne može se niti striktno propisati. Svaka ustanova, svi sudionici odgojnoobrazovnog procesa moraju biti usredotočeni prije svega na kvalitetan, holistički odgoj i učenje djece koji posredno ovisi o odgojiteljevom djelovanju odnosno vođenju, a neposredno o djelovanju odnosno vođenju svih ostalih sudionika.

Juul (2016) smatra da je djeci potrebno vođenje odraslih, ali ono više ne može biti onakvo kao nekad. Potrebno je uložiti trud i stvarati novo i drukčije. Smatra kako je najvažnije tradicionalni autoritet zamijeniti osobnim 
autoritetom, odnosno s osobnom odgovornošću, autoritet koji se temelji na ulozi mora se nadomjestiti osobnim autoritetom.

Ako na djecu želimo prenijeti određene obrasce ponašanja, onda je nužno da i odrasli prakticiraju iste obrasce. Gledano u kontekstu vodstva i odnosa među zaposlenicima važno je da su postavljeni na demokratskim, kolegijalnim i uvažavajućim temeljima pa će tada i djeca usvajati takve obrasce ponašanja. „Kvalitetnom suživotu djece i odraslih u vrtiću, temeljenom na demokratičnim načelima, međusobnom poštovanju i kvalitetnoj komunikaciji, pridonosi ravnomjerna distribucija moći u vrtiću“" (Nacionalni kurikulum, 2014: 40).

Promišljanja o vođenju u ustanovama ranog i predškolskog odgoja i obrazovanja sagledano kroz njezine specifičnosti i prirodu funkcioniranja navodi na zaključak kako se za kvalitetno vođenje može primijeniti više teorija i modela. Fenomen promjena jedno je od glavnih obilježje suvremenih ustanova za rani i predškolski odgoj i obrazovanje i iz tog razloga načine vođenja treba prilagođavati situaciji, kontekstu i sposobnostima zaposlenih, što $\mathrm{u}$ određenom smislu korelira s kontingencijskim teorijama vođenja. Kvalitetnu odgojno-obrazovnu praksu u ustanovama izgrađuju njezini djelatnici u skladu sa svojim profesionalnim znanjima. Izgradnju zajedničke vizije koja se postiže uključenošću i predanošću svih zaposlenih može poduprijeti model transformacijskog vođenja. Teorija distributivnog vođenja također nalazi mjesto u kontekstu ustanova ranoga i predškolskoga odgoja i obrazovanja i budući je kontekst sastavljen od više specifičnih međusobno povezanih podsustava koji su radi postizanja uspješnosti upućeni na suradnju. „Primjereno i odgovorno distribuirana moć u vrtiću važan je čimbenik 
postizanja fleksibilnosti odgojno-obrazovnoga procesa“ (Nacionalni kurikulum, 2014: 41).

Liderstvo treba biti dominantna i nezaobilazna uloga svih sudionika odgojno-obrazovne prakse, ne samo ravnatelja već i stručnih suradnika i odgojitelja uz uvažavanje činjenice da među njima postoji evidentna razlika $u$ intenzitetu i ekstenzitetu participacije u toj ulozi. Spajić je (2008) proveo istraživanje čiji cilj je bio utvrditi prisutnost liderskih svojstava, osobina i kompetencija te pedagoških svojstava kod 237 ispitanika iz redova ravnatelja, pedagoga i psihologa koji su zaposleni u osnovnim i srednjim školama Hrvatske. Iz dobivenih rezultata se zaključuje kako su ispitanici izdvojivši za njih najvažnija pedagoška svojstva ocijenili zapravo vlastite liderske karakteristike. Iako ispitanici prepoznaju liderske osobine kao bitna pedagoška svojstva koja su potrebna odgojno-obrazovnim djelatnicima u obrazovnim institucijama, samo je manja grupa ispitanika pokazala da imaju razvijene liderske vještine i sposobnosti. S ciljem utvrđivanja liderskih karakteristika i vještina kod zaposlenih u školama, a koje su poželjne za učinkovit rad u školi, Andevski i Arsenijević (2012) provele su istraživanje na uzorku od 252 ispitanika, ravnatelja, pedagoga, psihologa i učitelja. Rezultati istraživanja nedvojbeno su utvrdili postojanje predispozicija za vođenje, no nije se sa sigurnošću moglo utvrditi u kojoj su mjeri te vještine prisutne u stvarnom radu, stoga je opća hipoteza koju su postavile samo djelomično potvrđena i autorice upućuju na potrebu daljnjih istraživanja.

\section{ZAKLJUČAK}

Uspjeh odgojno-obrazovne ustanove nije individualno postignuće, već su kvalitetne promjene rezultat rada svih sudionika odgojno-obrazovnog 
procesa. To pretpostavlja otvorenost ustanove i pojedinačno preuzimanje odgovornosti.

Brojna provedena istraživanja potvrđuju da su optimalno vođenje, upravljanje i liderstvo u korelaciji s kvalitetnim funkcioniranjem svih, pa i odgojno-obrazovnih ustanova. Što je i kakvo je uistinu kvalitetno i učinkovito vođenje neovisno o kojoj se društvenoj razini ili organizaciji radi, pitanje je na koje se zasigurno ne može jednoznačno odgovoriti. Kvalitetno vođenje oblikuje i osnažuje zajedničku viziju ustanove. Andevski (2010) naglašava kako vođenje upravljano vizijom, označava spremnost na inovacije, iziskuje kompetencije koje ponekad imaju previše, a ponekad premalo demokratskih ideala $\mathrm{i}$ po svemu sudeći veliki su izazov za menadžment u odgojno-obrazovnim ustanovama. Distribucija moći i donošenje odluka u demokratskom okruženju osnova su uspješnog vođenja, a korištenje osobne moći te moći položaja na nezamjetljiv način karakteristike su uspješnog voditelja. Odlika kvalitetnog vođenja je dijeljenje moći i odgovornosti sa svim sudionicima odgojno-obrazovnog procesa, vođenje se temelji na znanju i mudrosti, a ne na poziciji i moći voditelja (Senge i sur. 2003). Yukl (2006) navodi kako uspješni voditelji koriste moć na fleksibilan način i s minimumom statusne razlike, ne ugrožavaju samopoštovanje uvažavajući interese drugih.

Pronalaženje učinkovitih načina vođenja kontinuirano predstavlja izazov za voditelje na svim društvenim razinama i u svim organizacijama. Liderstvo pretpostavlja dva temeljna umijeća, jedno je profesionalno stručno, što znači znanje o poslu koje se kontinuirano nadograđuje, a drugo je organizacijsko, navodi Grubić Nešić (2008). 
Ristić (1999) smatra kako svatko od zaposlenika mora znati svoju ulogu i, bez obzira što mu je posao, mora se ponašati kao lider i upravljati svojim radnim mjestom. Fullan i Hargreaves (1991 prema Stoll i Fink, 2000) navode kako je nužno da svaki pojedinac preuzme odgovornost za poboljšanje kvalitete cijele ustanove jer se u protivnom ona neće poboljšati. Svi sudionici odgojno-obrazovnog procesa imaju autonomnost i odgovornost, ali i obvezu spram vlastitog načina vođenja, te obvezu razvijati svoje voditeljske kompetencije i iz takve perspektive promišljati/propitivati o voditeljskim kompetencijama svojih suradnika i kolega. Obrazovne lidere treba pripremati za istraživače budućnosti s hrabrim srcima koji će biti radoznali i koji će bez straha otkrivati nove ideje, biti maštoviti i osporavati status quo tradicionalnoj obrazovnoj misli i za sobom ostavljati neizbrisive tragove jer oni su izabrala raditi za budućnost čovječanstva (Papa, 2016). Autorica Elliot-Johns (2015) smatra da treba više pažnje posvetiti pripremi i podršci dekanima obrazovanja za njihovo stalno stručno usavršavanje i održivo vodstvo kako u istraživanjima tako i u praksi. Staničić (2006) navodi primjer Švedske, gdje je praksa da se cjelokupno školsko osoblje osposobljava u području školskog menadžmenta kako bi mogli aktivno participirati u odlučivanju o važnim pitanjima škole osobito o unapređenju pedagoškog procesa. Voditelj mora biti ,sposoban i spreman ustanoviti činitelje uspješnog funkcioniranja skupine i organizacije i uspostaviti vezu među mnogobrojnim činiteljima i interakcijskim procesima“ (Lavrnja i Mušanović, 1993:113).

Zasigurno ne postoji idealan profil odgojitelja, stručnog suradnika ili ravnatelja, ali postoje osobine koje svakome od njih omogućuju da u 
profesionalnim izazovima više ili manje uspješno odolijevaju svojim slabostima.

Poznavanje znanosti o upravljanju samo po sebi neće dovesti do kvalitetnih promjena, za to je potrebno mnogo više. Potrebno je poznavati načine implementacija onoga što se zna i razumije. „Vjerujemo da se najznačajnije učenje događa u svakodnevnom životu, na razini naših težnji, izazova s kojima se suočavamo i rješenja koja pronalazimo“ (Senge i sur. 2003: 15). U budućnosti se očekuje od svih sudionika odgojno-obrazovnog procesa promicanje kulture samovođenja s ciljem razvijanja i unapređenja vlastitih voditeljskih potencijala.

\section{LEADERSHIP AS AN INDISPENSABLE FUNCTION OF THE EDUCATIONAL PROCESS IN THE CONTEMPORARY KINDERGARTEN CONTEXT}

\section{Abstract}

Performing quality of educational activities in the context of modern institutions of early and pre-school education requires professional pedagogical, didactic, and methodical knowledge acquired during the initial education, as well as adding and applying a number of other competences. This paper analyses the context of an institution for early and pre-school education in the light of contemporary paradigms in education, from which undoubtedly arises the need for the acquisition of new competences, with the emphasis on leadership competences that become essential pedagogical characteristics of all holders of the educational process (educators, expert associates, and headmasters). Accepting leadership as a process, by means of which one seeks to influence upon an individual or a group in certain situations in order to achieve certain goals, opens the need for a multidimensional view of this phenomenon.

Key words: leadership, management, management in education, education, early and pre-school education institutions. 


\section{REFERENCE}

Andevski, M. (2010). Obrazovanje za menadžment. Novi Sad: CEKOM book.

Andevski, M., \& Arsenijević, J. (2012). Leadership characteristics of schools' employees in Serbia. Industrija, 40(3), 147-168.

Andevski, M., Budić, S., \& Gajić, O. (2015). Koncept učenja direktora škola - situativno učenje. 13. Međunarodna naučno-stručna konferencija Doba znanja: Obrazovanje za menadžment (str. 14-19). Sremski Karlovci: Univerzitet „UNION-NIKOLA TESLA“, Fakultet za menadžment.

Bognar, L. i Matijević, M. (2005). Didaktika. Zagreb: Školska knjiga d.d.

Dimovski, V., Penger, S., \& Petrelin, J. (2009). Avtentično vodenje v učeči se organizaciji. Ljubljana: Planet GV, poslovno izobraževanje.

Došen-Dobud, A. (1982). Odgoj i slobodne aktivnosti predškolskog djetetaod igre do humanih vrijednosti. Zagreb: Radničko i narodno sveučilište „Moša Pijade“.

Drucker, P. (2005). Najvažnije o menadžmentu. Zagreb: MEP Consult.

Drucker, P. (2006). Upravljanje u budućem društvu. Zagreb: M.E.P. Consult.

Elliot-Johns, S.E. (2015). Insights gleaned from the voices of deans in education. In: S. E. Elliot-Johns (ed.), Leadership for change in teacher education (pp. 97-107). Rotterdam: Sense Publishers.

Fullan, M. ( 2003). The moral imperative of school leadership. London: Sage Publications.

Glasser, W. (2004). Teorija izbora, Nova psihologija osobne slobode. Zagreb: Alinea.

Grubić Nešić, L. (2008). Znati biti lider. Novi Sad: AB Print.

Jurčević-Lozančić, A. (2011). Socijalne kompetencije i rani odgoj. U: D.

Maleš (ur.), Nove paradigme ranog odgoja (str. 153-176). Zagreb:

Filozofski fakultet Sveučilišta u Zagrebu, Zavod za pedagogiju.

Jurčić, M. (2012). Pedagoške kompetencije suvremenog učitelja. Zagreb: RECEDO d.o.o.

Jurić, V. (2004). Pedagoški menadžment - refleksija opće ideje o upravljanju. Pedagogijska istraživanja, 1(1), 137-147.

Juul, J. (2016). Leitwolfe sein. Weinheim und Basel: Verlagsgruppe Beltz. 
Klippert, H. (2000). Teamentwicklung im klassenraum. Basel: Beltz Verlag.

Konja, V. (2014). Uticaj komunikacije lidera i saradnika na organizacionu posvećenost zaposlenih (doktorska disertacija). Novi Sad: Fakultet tehničkih nauka.

Kovač, J., Mayer, J., \& Jesenko, M. (2004). Stil in značilnosti uspešnega vodenja. Kranj: Založba Moderna organizacija v okviru FOV, Fleks d.o.o.

Lavrnja, I., \& Mušanović, M. (1993). Uspješno rukovođenje. U: Drandić, B. (ur.), Priručnik za ravnatelje (str. 111-123). Zagreb: Znamen.

Malik, F. (2009). Upravljati, stvoriti, živjeti. Zagreb: Mozaik knjiga d.o.o.

Maxwell, J. C. (2003). Razvijte vođu u sebi. Zagreb: V.B.Z. d.o.o.

Miljak, A. (2001). Odgojna praksa i okruženje u dječjim vrtićima. Napredak, 142(1), 7-15.

Mlinarević, V. (2004). Vrtićko okruženje usmjereno na dijete. Škola $i$ život, 11(1), 112-119.

Muldoon, J. (2015). Challenge and complexity in landscapes of change: Building effective partnerships. In: S. E. Elliot-Johns (eds.), Leadership for change in teacher education (pp. 81-87). Rotterdam: Sense Publishers.

Nacionalni kurikulum za rani i predškolski odgoj $i$ obrazovanje (2014). Zagreb: Ministarstvo znanosti, obrazovanja i sporta.

Papa, R. (2016). Footprints of educational leaders without borders. In: R. Papa \& F. W. English (Eds.), Educational leaders without borders (pp. 213-227). London: Springer Cham Heidelberg New York Dordrecht.

Peko, A., Mlinarević, V., \& Gajger, V. (2009). Učinkovitost vođenja u osnovnim školama. Odgojne znanosti, 11(2), 67-84.

Petrović-Sočo, B. (2007). Kontekst ustanove za rani odgoj i obrazovanjeholistički pristup. Zagreb: Mali profesor.

Resman, M. (2001). Ravnatelj, vizija škole i motivacija učitelja za suradnju. U: M. Silov (ur.), Suvremeno upravljanje i rukovođenje u školskom sustavu (str. 51-80). Velika Gorica: Persona.

Ristić, D. (1999). Osnovi menadžmenta. Novi Sad: CEKOM. 
Ristić, D. i saradnici (2008). Odabrana poglavlja iz menadžmenta. Novi Sad: „CEKOM“- books d.o.o.

Seme Stojnović, I., \& Hitrec, S. (2014). Suvremeno vođenje u odgoju $i$ obrazovanju. Zagreb: Golden marketing - Tehnička knjiga.

Senge, P. M., Kleiner, A., Roberts, C., Ross, R., Roth, G., \& Smith, B. (2003). Ples promjene - izazovi u razvoju učećih organizacija. Zagreb: Mozaik knjiga.

Sindik, J. (2012). Razlike u doživljaju učinkovitosti timskog rada s obzirom na dob i profil stručnjaka u predškolskom odgoju i obrazovanju. Magistra Iadertina, 7(7), 55-72.

Slunjski, E. (2006). Stvaranje predškolskog kurikuluma u vrtiću organizacija koja uči. Zagreb - Čakovec: Mali profesor - Visoka učiteljska škola.

Slunjski, E. (2009). Postizanje odgojno-obrazovne prakse vrtića usklađene s prirodom djeteta i odraslog. Život i škola: časopis za teoriju i praksu odgoja i obrazovanja, 55(22), 104-115.

Slunjski, E. (2015). Izvan okvira. Zagreb: Element d.o.o.

Slunjski, E. (2018). Izvan okvira 3, Vođenje: prema kulturi promjena. Zagreb: Element d.o.o.

Slunjski, E., Ljubetić, M., Pribela-Hodap, S., Malnar, A., Kljenak, T., Zagrajski Malek, S., Horvatić, S., \& Antulić. S. (2012). Priručnik za samovrednovanje ustanova ranog $i$ predškolskog odgoja $i$ obrazovanja. Zagreb: Nacionalni centar za vanjsko vrednovanje obrazovanja.

Spajić, B. (2008). Liderske karakteristike u obrazovnim institucijama. Doktorska disertacija, Novi Sad: Samostalni nedržavni Univerzitet Privredna Akademija Fakultet za menadžment.

Srića, V. (2004). Inventivni menadžer u 100 lekcija. Zagreb: Znanje d.d., Delfin-razvoj menagmenta.

Staničić, S. (2005). Uloga i kompetencije školskih pedagoga. Pedagogijska istraživanja, 2(1), 35-47.

Staničić, S. (2006). Menadžment u obrazovanju. Rijeka: Vlastita naklada.

Stojković, J., \& Katovčić, S. (2016). Profesionalni razvoj i cjeloživotno učenje odgojitelja. U: N. Tatković, M. Radetić-Paić, I. Blažević, I., \& 
S. Verbanac (ur.), Suvremeni modeli rada u dječjem vrtiću $i$ kompetencije odgojitelja (str. 67-76). Medulin.

Stoll, L., \& Fink, D. (2000). Mijenjajmo naše škole: Kako unaprijediti djelotvornost $i$ kvalitetu škola? Zagreb: Educa.

Šagud, M. (2006). Odgajatelj kao refleksivni praktičar. Petrinja: Visoka učiteljska škola u Petrinji.

Tudor, G., Rijavec, M., \& Zarevski, P. (2009). Menadžerska učinkovitost $360^{\circ}$. Zagreb: M.E.P. d.o.o.

Tudor, G., \& Srića, V. (2014). Menadžer i pobjednički tim. Zagreb: M.E.P. d.o.o.

Vujičić, L. (2008). Kultura odgojno-obrazovne ustanove i kvaliteta promjena odgojno obrazovne prakse. Pedagogijska istraživanja, 5(1), 7-20.

Yukl, G. (2006). Leadership in organizations. New Jersey: Pearson Education. 